\title{
Herstellung von
}

(S)-4-Methyloxetan-2-on

( $\beta$-Butyrolacton) durch

Lactonisierung von $(R)$-3-Hydroxybuttersäure mit Orthoessigsäuretriethylester

\author{
Richard Breitschuh [1] und Dieter Seebach*
}

Abstract. The readily available $(R)-3$-hydroxybutanoic acid (1) was treated with triethyl orthoacetate, with azeotropic removal of ethanol, to yield $(6 R)$-2-ethoxy-2,6-dimethyl1,3-dioxan-4-one (3a). Pyrolysis of 3a led to the $\beta$-lactone of $(S)$-3-hydroxybutanoic acid and other products. The influence of pressure, temperature, solvents, and some additives has been tested. A procedure for preparing $(S)$-4-methyloxetan-2-one (4) in a 0.25 -mol scale is described.

Ausgehend von $(R)$ - oder $(S)$-3-Hydroxybuttersäure (1, ent-1) [2] ergeben sich zahlreiche Umwandlungsmöglichkeiten unter Erhalt der OH-Funktion [3-12]. Ein Austausch dieser Gruppe gegen andere Reste ist zwar über Sulfonate der Ester (z. B. 2) möglich, doch ist diese Methode ten [21][22] Sequenz Säure 1, Dioxanon 3a, Lacton 4 und Substitutionsprodukt zu ent a unter zweifacher Inversion insgesamt eine Retention der Konfiguration [23][24] (Schema). Mit $\mathrm{H}_{2} \mathrm{O}$ reagiert das Lacton 4 unter neutralen Bedingungen mit Inversion zu 1, unter stark basischen Bedingun-

Schema<smiles>CCOC(=O)OCC(=O)OC1(C)OC(=O)C[C@@H](C)O1</smiles><smiles>C[C@@H](O)CC(=O)O</smiles>
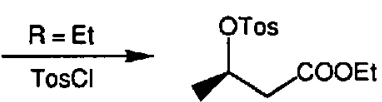

3a<smiles>C1CC1</smiles>

$1(R=H)$

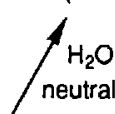<smiles>C[C@H](O)CC(=O)O[14C](=O)[14CH]([14CH3])O</smiles>

$e n t-1$
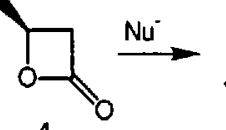

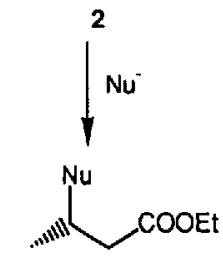

auf wenige Beispiele beschränkt, in denen der Anteil der Racemisierung vernachlässigbar blieb [13-15]. Mehr Möglichkeiten bietet der Weg über das Lacton (4 oder ent-4). Dieses reagiert mit C-, $\mathrm{N}$-, $\mathrm{O}$ - und S-Nukleophilen zu 3-substituierten Buttersäuren [16-21]. Während der Weg über die Tosylate unter Inversion zu a verläuft [1315], resultiert bei der vor kurzem entdeck-

\footnotetext{
* Korrespondenz: Prof. Dr. D. Seebach Laboratorium für Organische Chemie Eidgenössische Technische Hochschule Zürich ETH-Zentrum, Universitätstrasse 16 CH-8092 Zürich
}

5<smiles>C[C@@H](CC(=O)O)OC1OC(=O)C[C@H](C)O1</smiles>

6b<smiles>CCCC(C)(OC(C)CC(=O)O)OC(C)CC(=O)O</smiles>

6a Trimethyl-ortho-
tionsfolge $1 \rightarrow 4$
beuten zum Cy-
ibt zu einem be-
fe der offenketti-
5 stehen, deren
den Pyrolyse-
Einsatz von Or-
pylester werden
"dimeren» offen-
rthoesters 6a und
nen gebildet [27].
ter verschiedener
oxanone vom Typ
hoameisensäure-
ben sich dadurch
erst bei höheren
und geringere
lieferten. Ortho-
ohlensäure-ester
nliches Pyrolyse-
oessigsäure-Deri-
läufer aber billimöglich, (S)-3-Hydroxybuttersaure (ent-1) aus dem $(R)$-Enantiomeren 1 $(\mathrm{R}=\mathrm{H}) \mathrm{zu}$ gewinnen.

Das Lacton 4 in enantiomerenreiner Form ist bereits seit 1938 via Racamatspaltung der 3-Brombuttersäure zugänglich, jedoch nur in kleineren Mengen [16][25]. Wie oben erwähnt, ist es möglich, das Lacton 4 auch durch Pyrolyse von 6-Methyl1,3-dioxan-4-onen $3 \mathrm{zu}$ erhalten, deren Verlauf im folgenden eingehend erörtert wird. Die früher von uns publizierte Vorschrift [21] ist anfällig gegenüber Einflüssen, die erst durch die jetzt vorliegende Untersuchung der Reaktionen erkannt wurden.

Die Verwendung von Trimethyl-orthoestern führt in der Reaktionsfolge $1 \rightarrow 4$ nur in ungenügenden Ausbeuten zum $\mathrm{Cy}$ clus 3. Die Reaktion bleibt zu einem bedeutenden Teil auf der Stufe der offenkettigen Zwischenprodukte 5 stehen, deren Säurefunktion vermutlich den Pyrolyseverlauf stört [26]. Beim Einsatz von Orthoameisensäure-triisopropylester werden andererseits 10-20\% der "dimeren» offenkettigen und cyclischen Orthoesters 6a und 6b mit zwei Säurefunktionen gebildet [27]. Wir setzten dann Orthoester verschiedener Säuren ein, aus denen Dioxanone vom Typ 3 erzeugt wurden. Die OrthoameisensäureDerivate $3 \mathbf{c}-\mathbf{e}(\mathrm{R}=\mathrm{H})$ hoben sich dadurch $a b$, dass ihre Pyrolysen erst bei höheren Temperaturen einsetzten und geringere Ausbeuten an Lacton 4 lieferten. Orthobenzoesäure- und Orthokohlensäure-ester 3f und $3 g$ zeigten sehr ähnliches Pyrolyseverhalten wie die Orthoessigsäure-Derivate $3 \mathbf{a}$ und $\mathbf{3 b}$, deren Vorläufer aber billiger sind.

Daher setzten wir in der Folge Orthoessigsäure-triethylester als das Reagenz unserer Wahl ein, welches die Herstellung von (6R)-2-Ethoxy-2,6-dimethyl-1,3-dioxan-4-on (3a) in hoher Ausbeute und Reinheit ermöglicht.

Bei der Optimierung der Herstellung von 3a erwies sich die Wahl des Lösungsmittels und der Reaktionstemperatur als entscheidend. Mit Hilfe des Lösungsmittels soll das freiwerdende EtOH azeotrop
abdestilliert werden. Zahlreiche Lösungs-

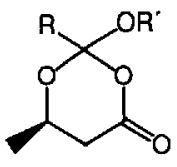

$3 a-9$

3a: $R=M e, R^{\prime}=E t$ 3b: $R=M e, R^{\prime}=M e$ 3c: $R=H, R^{\prime}=M e$ 3d: $R=H^{\prime}, R^{\circ}=E t$ 3e: $R=H, R^{\prime}=i-P r$ 3t: $R=P h, R^{\prime}=E t$ 3g: $R=O E t, R^{\prime}=E t$

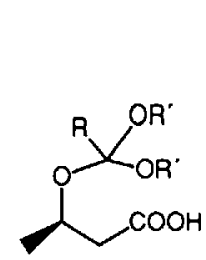

$\mathrm{CH}_{3} \mathrm{COOEt}$

$\mathrm{CH}_{2}=\mathrm{CH}-\mathrm{CH}_{3}$

$\mathrm{CO}_{2}$

8

9
10<smiles>CCOC(=O)C[C@@H](C)OC(C)=O</smiles>

7 .
$\underbrace{\mathrm{AcO}} \underbrace{\mathrm{O}} \mathrm{COOH}$

11 
mittel bilden Azeotrope mit EtOH (z. B. $\mathrm{MeCN}$, Benzol, Hexan und Toluol), deren oft zu hohe Siedepunkte fördern aber die säurekatalysierte Umlagerung des Orthoesters 3a zum Acetoxyester 7 [26]. Unter den Cyclisierungsbedingungen zu 3a reichen hierzu Carbonsäuren aus (z. B. 1 und 5), die Umlagerung ist aber bei Temperaturen unter $65^{\circ}$ langsam genug, so dass Produktgemische mit weniger als $2 \%$ des offenkettigen Esters 7 entstanden. Auch die Bildung von Essigsäure-ethylester (8), Propen (9) und $\mathrm{CO}_{2}$ (10) (Gase-Entwicklung) macht bei diesen Temperaturen weniger als $10 \%$ aus. Das Konstanthalten der Innentemperatur auf $\mathrm{ca} .60^{\circ}$ erfordert allerdings die Reaktionsführung unter vermindertem Druck, welcher mit fortschreitender Reaktion, d.h. veränderter Zusammensetzung des Reaktionsgemisches, laufend abgesenkt werden muss. Obwohl sich 3a über ionische Zwischenstufen bilden sollte, bringt der Einsatz des polaren MeCN keinen Vorteil; etwa 5-8\% reagieren in $\mathrm{MeCN}$ nur bis zur offenen Form 5 , in Benzol sind die Resultate vergleichbar. Verwendet man dagegen Toluol, so sind im entstandenen Acetal 3a keine sauren $\mathrm{H}$ Atome 'H-NMR-spektroskopisch nachweisbar [26]. Für die Bildung des Acetals 3a ist folglich weniger die Reaktionsgeschwindigkeit als vielmehr die Fähigkeit des Schleppmittels ausschlaggebend, EtOH dem Gleichgewicht effizient zu entziehen.

Auf den Verlauf der Pyrolyse des cyclischen Orthoesters 3a hat Säure einen entscheidenden Einfluss: In Gegenwart von Säure entsteht überwiegend $\operatorname{der}(R)$-konfigurierte Ester 7, während sich das $(S)$-Lacton 4 nur in Spuren bildet. Um die störenden Säurereste abzufangen, wurden bei der Pyrolyse diverse Basen zugesetzt, welche alle in einer unerwünschten Nebenreaktion zur Bildung von Oligomeren, z. B. des Dimeren 11, Anlass gaben. Diese Oligomerisierung nahm bei $\mathrm{Na}_{2} \mathrm{CO}_{3}$ und basischem $\mathrm{Al}_{2} \mathrm{O}_{3}$ in weit grösserem Masse am Reaktionsverlauf teil als bei $\mathrm{K}_{2} \mathrm{CO}_{3}$ oder $\mathrm{CaH}_{2}$. Basisches $\mathrm{Al}_{2} \mathrm{O}_{3}$ bewirkte überdies die Entstehung von $c a .5 \%$ Crotonsäure.

Temperatur- und Druckabhängigkeit der Pyrolyse in Gegenwart von $\mathrm{CaH}_{2}$ gehen aus der Tabelle hervor. Die Pyrolyse setzt bei $80-90^{\circ}$ ein, durchläuft bei $90-100^{\circ}$ ein Optimum und führt bei höherer Temperatur in immer stärkerem Masse zur Fragmentierung $(\rightarrow \mathbf{8 - 1 0})$. Bei Normaldruck entstehen unter diesen Bedingungen

Tabelle. Maximal erreichte Ausbeuten an Lacton 4 bezogen auf eingesetzten cyclischen Orthoesters 3a be Verwendung von $\mathrm{O} / \mathrm{g} \mathrm{CaH}$ auf je $10 \mathrm{~g}$ Acetal 3a. Dic für den jeweils vollständigen Umsatz von 3a benötigte Zeit lag zwischen 45 min und $2 \mathrm{~h}$

\begin{tabular}{lcccc}
\hline Druck & \multicolumn{3}{c}{ Ausbeute [\%] bei } \\
& $80^{\circ}$ & $90^{\circ}$ & $100^{\circ}$ & $110^{\circ}$ \\
\hline 1 Torr & - & 39,2 & 39,1 & 22,6 \\
2 Torr & - & 40,7 & 35,6 & - \\
3 Torr & - & 36,1 & 18,9 & - \\
50 Torr & - & 18,8 & - & - \\
1 atm & 27,1 & 30,5 & 27,0 & - \\
\hline
\end{tabular}

neben dem Lacton 4 zu etwa $20 \%$ Oligomere (11 und höhere), zu 30-40\% der Ester 7, und zu 10-20\% tritt Fragmentierung ein. Obwohl unterhalb von 5 Torr kein Ester 7 gebildet wird, ist die Ausbeute an Lacton 4 nicht wesentlich höher, da nun die Fragmentierung mit etwa $40-50 \%$ in den Vordergrund tritt. Bei mittleren Drukken von ca. 50 Torr stören alle Nebenreaktionen in ähnlichem Masse, so dass die Lacton-Ausbeute hier ein Minimum durchläuft. Bezüglich des Druckes gibt es folglich zwei Maxima, eines bei etwa 2 Torr und das andere bei Normaldruck. Je mehr $\mathrm{CaH}_{2}$ zugesetzt wird, desto mehr EtOH enthält das Destillat. Je mehr von diesem EtOH andererseits im Reaktionsgemisch verbleibt, desto mehr Acetoxyester 7 bildet sich. Wird das freigesetzte EtOH dem Reaktionsmedium sofort entzogen, lässt sich aber die Entstehung von 7 völlig unterdrücken. Die Ausbeuten und Reaktionszeiten unterliegen beim Zusatz von $\mathrm{CaH}_{2}$ starken Schwankungen, und grössere Ansätze liefern vor allem im Druckbereich unter 5 Torr bei längerer Reaktionsdauer deutlich niedrigere Ausbeuten. Damit bringt bei der Pyrolyse der Zusatz von Basen, welcher die säurekatalysierte Umlagerung des cyclischen Orthoesters 3a zum Acetoxyester 7 verhindern sollte, keinen Vorteil!

Die Herstellung vom Dioxanon 3a erforderte also: möglichst tiefe Temperaturen und einen möglichst vollständigen Reaktionsverlauf, damit einerseits die Weiterreaktion zu 7-10 unterbleibt und andererseits ein säure- und $\mathrm{EtOH}$-freies reines Edukt 3a für die anschliessende Pyrolyse in Abwesenheit von Base vorliegt. Die zweite Stufe, die Pyrolyse von 3a zu 4, zwischen 90 und $100^{\circ}$ musste unter Bedingungen erfolgen, bei denen kleine Säure und kein EtOH entsteht (strenger Feuchtigkeitsausschluss [28]).

Als optimierte, mit einmolaren Ansätzen reproduzierbare, wenn auch bezüglich Ausbeute nicht befriedigende, Durchführung ergibt sich: die Kondensation der $\mathrm{Hy}$ droxybuttersäure 1 mit Orthoessigsäuretriethylester zum Dioxanon 3a in Toluol bei $60^{\circ}$ unter azeotroper Entfernung vom gebildeten EtOH im Vakuum und anschliessende Pyrolyse in Gegenwart von 5 $\AA$ A-Molekularsieb [29] bei $90-100^{\circ}$ unter Normaldruck, wobei AcOEt, Propen und $\mathrm{CO}_{2}(\mathbf{8}-10)$ entweichen. Der Rückstand besteht aus $(S)$ - $\beta$-Lacton 4 und $(R)$-Acetoxyester 7 , die destillativ getrennt werden (Sdp.: 55 bzw. $75 \% 12$ Torr). Eine ausführliche Vorschrift folgt, eines Kommentars über den Mechanismus der Pyrolyse enthalten wir uns, weil die beobachteten Einflüsse der Bedingungen auf den Verlauf der Reaktion unseres Erachtens nicht mit einem einfachen Modell vereinbar sind [30].

\section{Experimentelles}

(6R)-2-Ethoxy-2,6-dimethyl-1,3-dioxan-4-on (3a). Ein 2-1-Zweihalskolben wird mit einem Stopfen und einer Destillationsbrücke mit Vorlage verschen, auf die ein Dreiweghahn, eine mit Trockeneis/Aceton gekühlte Kühlfalle, ein Druckregler und eine Wasserstrahlpumpe folgen. Im Kolben werden unter Ar $104 \mathrm{~g}$ (1 mol) über $\mathrm{P}_{2} \mathrm{O}_{5}$ getrocknete ( $\mathrm{R}$ )-3-Hydroxybuttersäure (1) und 11 Toluol vorgelegt und mittels Magnetrührstab 15 min lang bei RT. gerührt, so dass der Hauptteil von 1 in Lsg. geht. Daraufhin werden 1628 (1 mol) Orthoessigsäure-triethylester zugegeben und der Stopfen gegen eine Serumkappe ausgetauscht, um die Innentemp. mit Hilfe eines Thermoelementes beobachten zu können. Der Druck wird auf 270 mbar abgesenkt und die Mischung mittels Ölbad unter Rühren erwärmt. Die Ölbadtemp. wird 2 h lang auf $75^{\circ}$ gehalten und während dieser Zeit der Druck derart bis auf 140 mbar abgesenkt, dass die Innentemp. stets bei $60^{\circ}$ und die Kopftemp. bei $55^{\circ}$ liegt. Es destillieren in dieser Zeit rund $850 \mathrm{ml}$ eines EtOH-Toluol-Gemisches ab. Daraufhin wird die Badtemp. rasch auf $40^{\circ}$ abgesenkt, indem fein zerstossenes Trockeneis in kleinen Portionen auf die Oberfläche des Ölbades gegeben wird, und innerhalb I h werden bei 24 mbar weitere 160 $\mathrm{ml}$ Lsgm. abdestilliert. Die Destillationsbrücke wird gegen einen Dreiwegehahn mit Kernschliff ausgetauscht und das Produkt bei RT. und 0,1 Torr $2 \mathrm{~h}$ lang von den verbliebenen Lsgm.-Resten befreit, so dass $160-162 \mathrm{~g}(92-93 \%)$ rohes 3a verbleiben. Das ' $\mathrm{H}$ NMR (200 $\mathrm{MHz}, \mathrm{CDCl}_{3}$ ) zeigt dic beiden Diastereoisomere von 3a im Verhältnis $5: 2$. Hauptisomer: 1.22 $\left(t, J=7.0, \mathrm{CH}_{3} \mathrm{CH}_{2} \mathrm{O}\right) ; 1.27\left(d, J=6.5, \mathrm{CH}_{3}-\mathrm{C}(6)\right)$ $1.67\left(s, \mathrm{CH}_{3}-\mathrm{C}(2)\right) ; 2.33(d d, J=16.5,9.5, \mathrm{H}-\mathrm{C}(5))$; $2.66(d d, J=16.5,4.5, \mathrm{H}-\mathrm{C}(5)) ; 3.67\left(m, \mathrm{CH}_{3} \mathrm{CH}_{2} \mathrm{O}\right)$ $4.53(\mathrm{~m}, \mathrm{H}-\mathrm{C}(6))$; anderes Diastereoisomer: $1.22(t$ $\left.J=7.0, \mathrm{CH}_{3} \mathrm{CH}_{2} \mathrm{O}\right) ; 1.35\left(d, J=6.0, \mathrm{CH}_{3}-\mathrm{C}(6)\right) ; 1.68$ $\left(s, \mathrm{CH}_{3}-\mathrm{C}(2)\right) ; 2.49(d d, J=16.5,10.0, \mathrm{H}-\mathrm{C}(5)) ; 2.62$ $(d d, J=16.5,4.0, \mathrm{H}-\mathrm{C}(5)) ; 3.67\left(m, \mathrm{CH}_{3} \mathrm{CH}_{2} \mathrm{O}\right) ; 4.17$ (m, $\mathrm{H}-\mathrm{C}(6))$.

(S)-4-Methyloxetan-2-on (4). In einem 250-mlRundkolben mit aufgesetzter $10 \mathrm{~cm}$ Vigreux-Kolonne, Destillationsbrücke mit Vorlage und nachfolgend einem Dreiwegehahn werden unter Ar $2 \mathrm{~g}$ frisch aktiviertes 5-A-Molekularsieb vorgelegt. Die oben erhaltenen 160-162 g Acetal 3a werden mit einer Spritze via Serumstopfen am Kopf der Destillationsbrücke zugegeben und die Serumkappe durch einen Glasstopfen ersetzt. Zunächst wird mittels Magnetfisch $30 \mathrm{~min}$ bei RT. gerührt, danach der Kolben in ein auf $100^{\circ}$ vorgeheiztes Ölbad gebracht. Unter kräftigem Rühren wird 60-80 min pyrolysiert unter Abdestillicren von $45 \mathrm{~g}$ AcOEt. Der vollständige Umsatz von 3a wird daran erkannt, dass die durch teilweise Fragmentierung von 3a verursachte Gasentwicklung aufhört. Durch vorsichtiges Evakuieren der Apparatur wird zunächst der restliche AcOEt abdestilliert und dann bei 12 Torr $/ 55^{\circ}$ (Kopftemp.) 4 (2l--22 g; ca. $25 \%$ bzg. 1; für die anal. Daten s. [16][21][25]) überdestilliert. Als Rückstand verbleiben $24-25 \mathrm{~g} 7$ (ca. 14\%) [31].

Eingegangen am 4. April 1990

[1] Teil der geplanten Dissertation von $R$. Breitschuh, ETH Zürich.

[2] Das $(R)$-Enantiomere 1 lässt sich durch saure $\mathrm{Hy}$ drolyse direkt aus dem Biopolymeren Polyhydroxybuttersäure (PHB) herstellen, wenn dieses zunächst in situ $\left(\mathrm{C}_{2} \mathrm{H}_{4} \mathrm{Cl}_{2} / \mathrm{Säure} \mathrm{McOH}\right)$ zu Oligomeren umgeestert wurde (D. Seebach, A.K. Beck $R$. Breitschuh, K. Job, bei Organic Synthesis eingereichte Vorschrift)

[3] G. Fráter, Helv. Chim Acta 1979, 62, 2829.

[4] M.A. Sutter, D. Seebach, Liebigs Ann. Chem. 1983, 939; D. Seebach, H.-F. Chow, R.F.W Jackson, M. A. Sutter, S. Thaisrivongs, J. Zimmermann, ibid. 1986, 1281 .

[5] E. Hungerbühler, D. Seebach, D. Wasmuth, Helv. Chim Acta 1981, 64, 1467.

[6] D. Seebach, J. Zimmermann, Helv. Chim. Acto $1986,69,1147$

[7] J. Zimmermann, D. Secbach, Helv. Chim. Acto $1987,70,1104$

[8] D. Seebach, S. Roggo, J. Zimmermann, in 'Stereochemistry of Organic and Bioorganic Transformations', Workshop Conferences Hoechst, Schloss Reisenburg, Eds. W. Bartmann und K. B. Sharpless, Verlag Chemie, Weinheim, 1987, Vol.17, pp. 85-126. 
[9] D. Seebach, J. Zimmermann, U. Gysel, R. Ziegler, T. Ha, J. Am. Chem. Soc. 1988, II0, 4763.

[10] J. Zimmermann, D. Seebach, T. Ha, Helv. Chim. Acta 1988, 71, 1143 .

[11] W. Amberg, D. Seebach, Angew. Chem. 1988, 100, 1786; ibid. Int. Ed. 1988, 27, 1718.

[12] D. Seebach, U. Misslitz, P. Uhlmann, Angew. Chem. 1989, 101, 484; ibid. Int. Ed. 1989, 28, 472.

[13] H. Liu, R. Auchus, C.T. Walsh, J. Am. Chem. Soc. 1984, 106, 5335 .

[14] G. Cainelli, F. Manescalchi, G. Martelli, M. Panunzio, L. Plessi, Tetrahedron Lett. 1985, 26, 3369.

[15] R. Imwinkelried, Dissertation Nr.8142, ETH Zürich, 1986.

[16] A. R. Olson, R. J. Miller, J. Am. Chem. Soc. 1938 , 60. 2687.

[17] A. R. Olson, P. V. Youle, J. Am. Chem. Soc. 1951, 73, 2468.

[18] T. Sato, T. Kawara, A. Nishizawa, T. Fujisawa, Tetrahedron Lett. 1980, 21, 3377.

[19] T. Fujisawa, T. Sato, T. Kawara, K. Ohashi, Te trahedron Lett. 1981, 22, 4823.

[20] T. Sato, K. Naruse, T. Fujisawa, Tetrahedron Lett. 1982, 23, 3587.

[21] A. Griesbeck, D. Seebach, Helv. Chim. Acta 1987, $70,1320$.

[22] A. Griesbeck, D. Seebach, Helv. Chim. Acta 1987 , $70,1326$.

[23] Die Lactonisierung von 2-Alkyl-2-(hydroxymethyl)-carbonsäuren durch Erhitzen mit Orthoestern ist seit langem bekannt [24].
[24] R.C. Blume, Tetrahedron Letl. 1969, 13, 1047 R. C. Blume, US-Patent No. 3.503.993, 1970 ( $C A$ $1970,73, \mathrm{P}$ 14860z)

[25] H. Johansson, Lunds Universtets Arsskrift. N.F. Avd.2 1916, 12. No.8; H. Johansson, Chem. Zentr.II 1916, 557.

[26] Bei der Pyrolyse von unreinem Orthoester 3a (nach ${ }^{\mathrm{I}} \mathrm{H}-\mathrm{NMR}$ noch $\mathrm{Ca} .10 \% \mathrm{COOH}$-Wasserstoffe enthaltend) bei 2 Torr entstand zu über $30 \%$ der Ester 7. Dieser Anteil verminderte sich bei der Zugabe von $\mathrm{CaH}_{2}, \mathrm{NaCO}_{3}, \mathrm{~K}_{2} \mathrm{CO}_{3}$ oder $\mathrm{Al}_{2} \mathrm{O}_{3}$ vor der Pyrolyse. Wenn die doppelte der zum Abfangen der $\mathrm{COOH}-W a s s e r s t o f f e$ benötigten Menge einer Base wie $\mathrm{CaH}_{2}$ oder $\mathrm{K}_{2} \mathrm{CO}_{3}$ zuvor zugesetzt wurden, unterblieb die Entstehung von 7. Destillativ gereinigter Orthoester 3a lagerte be Zugabe starker Säuren (z. B. TsOH) oder LewisSäuren (z. B. BF $F_{3} \cdot \mathrm{Et}_{2} \mathrm{O}$ ) bereits bei RT. rasch zu 7 um.

[27] Nach der Umsetzung von $(R)-3$-Hydroxybuttersäure (1) mit Orthoameisensäure-triisopropylester in MeCN ging aus dem ' $\mathrm{H}$-NMR-Spektrum hervor, dass $\mathrm{ca}$. $60 \%$ des Orthoesters als eine $(1: 1)$ Mischung der beiden Diastereoisomeren von $3 \mathrm{e}$ $(\delta=6.00$ bzw. $6.05 \mathrm{ppm}), c a .15 \%$ des unverbrauchten Edukts $(\delta=5.31 \mathrm{ppm})$ und $c a .7 \%$ Ameisensäure-ester $(\delta=8.02 \mathrm{ppm})$ vorlagen. Weitere 6 bzw. $12 \%$ des Materials zeigen ${ }^{1} \mathrm{H}$ NMR-Signale in den für offenkettige bzw. cyclische Orthoameisensāure-ester charakteristischen Bereich, d.h. es liegen vermutlich Orthoester vor, die zwei Hydroxybuttersäure-Einheiten pro Molekül enthalten (6a bzw. 6b). Den freien Säurefunktionen wird ein breites Signal bei $\delta=7.60 \mathrm{ppm}$ zugeordnet, dessen Intensität ca. $20 \%$ der Hydroxybuttersäure-Einheiten entspricht.

[28] Der Orthoester 3a reagiert mit $\mathrm{H}_{2} \mathrm{O}$ spontan zu (R)-3-Hydroxybuttersäure (1), EtOH und AcOEt.

[29] Durch Zusatz von Molekularsieb werden die letzten Reste an EtOH, die noch im Reaktionsgemisch verblieben, gebunden. Einen ähnlichen Effekt hat zwar das Anlegen von Vakuum bei der Pyrolyse, es tritt dann aber in höherem Masse Fragmenticrung ein.

[30] Verdünnung des Orthoesters 3a mit polaren (DMPU, $\left(\mathrm{Bu}_{4} \mathrm{~N}^{+} \mathrm{H}_{3} \mathrm{CSO}_{3}^{-}\right)$-Schmelze) wie auch mit unpolaren Lsgm. (Toluol) verlangsamt die $\mathrm{Py}$ rolyse. Verläuft die Umlagerung zu 7 über eine Dissoziation von 3a oder durch Spuren von EtOH? AIBN-Zusätze bewirken keine Änderung des Pyrolyseverlaufes! Basen beschleunigen - unreproduzierbar - die Lactonbildung! Ist die Fragmentierung zu 8-10 eine Retro- $(2+2+2)$-Cycloaddition, oder erfolgt sie über dasselbe mutmassliche zwitterionische Zwischenprodukt, über welches sich das Lacton $\mathbf{4}$ unter Inversion bildet (s. unseren früheren Vorschlag [21])?

31] Bei kleineren Ansätzen von 50-200 mmol lagen die Ausbeuten an Lacton 4 bei $26-29 \%$, der Acetoxyester 7 entstand zu 2-5\%.

\section{Otto Isler}

\section{On the Occasion of his 80th Birthday}

Nature has always stood as a model for chemists, and much of their synthetic activity can be attributed to their desire to get close to the secrets of life. Dr. Otto Isler was one of those who took the opportunity to use his knowledge to give chemistry something of the power of nature, and his own research reflects the benefits which can be achieved with it. Isler is the chemis who synthesized lipid-soluble vitamins for industry, after their structure had been elucidated, and it is for this achievement that he will be known to history.

Otto Isler was born on August 4, 1910 in Schaffhausen, just when the old century was phasing out, and the new one was about to announce its turbulent commencement. Isler began his study of chemistry at the ETH in Zurich in those years when the turmoil was somewhat less intense. There he became acquainted with the work of Prof. Leopold Ruzicka and his study of natural compounds such as terpenes, and with them the principle of the isoprene unit. This then led Isler to write a dissertation on the white titanium pigment of the birch tree betulin. Wishing to expand his knowledge of the chemistry of natural substances, he went to Rockefeller Institute in New York to work for two years with W.A. Jacobs on sapogenines.

However, it was not only the influence of Prof Leopold Ruzicka which steered Isler in the direction of lipid substances of natural origin. The chromatography of Tswett introduced him to the yellow and red compounds of the plant world, the carotenoids. Other researchers, such as Willstätter, increased the young Isler's interest in the role of chlorophylls and carotenoids in photosynthesis. Around 1928, Zechmeister was able to show spectroscopically that the color of the carotenoids was due to the conjugation of their double bonds. But with the elucidation of the structure of vitamin $A$ and $\beta$-carotene by Prof. Paul Karrer of the University of Zurich in the 1930's, the crucial step was accomplished toward their chemical synthesis.

Otto Isler's interest in organic chemistry carried him in 1936 to F. Hoffmann-La Roche \& Co., Basel. It was there that he pulled all his experience and talent together to synthesize a whole series of valuable lipidsoluble vitamins. He began with the first total synthesis of vitamin $E$ in 1938, followed by vitamin $K_{1}$ in 1939. However, the one aspect of his all encompassing work for which Otto Isler is most renown, is the synthesis of vitamin A in 1947. The large-scale industrial manufacture of vitamin A acetate or palmitate allowed the economical production of highly stable pharmaceutical

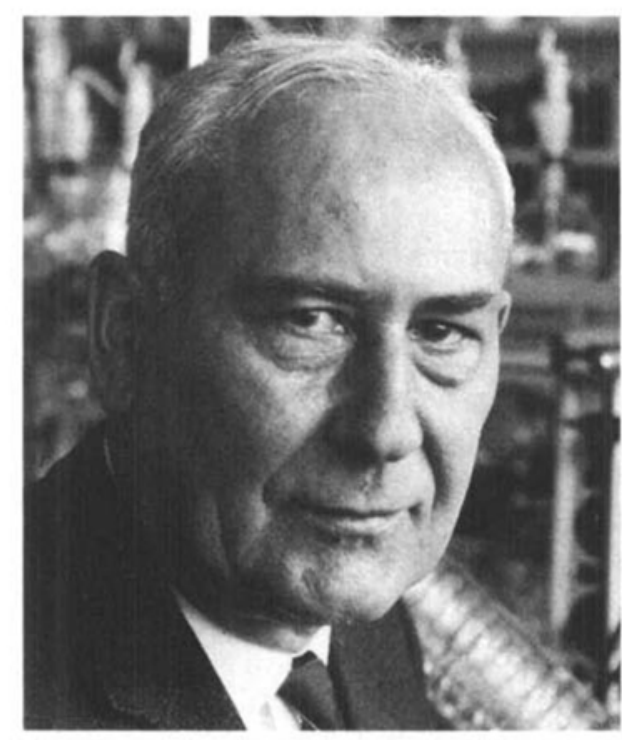

forms such as gelatine capsules. Thus, it was no longer necessary to rely on expensive and decomposable liver extracts to fight night-blindness and other forms of vitamin A deficiency throughout the world.

One thing leads to the other, and with his experience in vitamin A synthesis. Otto Isler began to work on the industrial synthesis of the various carotenoids. In 1954 , Roche introduced synthetic $\beta$-carotene for the coloring of margarine. Then in $1960, \beta$-apo- $8^{\prime}$-carotenal, in $1962 \beta$-apo- $8^{\prime}$-carotenoic acid ester, and in 1964 can- thaxanthin were introduced for the coloring of food and feedstuffs. They have been extremely valuable in replacing the toxic red and yellow azo dyes used as coloring agents. Recently, the carotenoids have been postulated as being beneficial for health and growth. Studies conducted by several researchers have indicated that $\beta$-carotene has properties associated with the prevention of various cancers. Large-scale intervention studies are being carried out right now to document these observations, but without the clearly defined synthetic isomers of $\beta$-carotene it would not be possible to conduct such studies.

Otto Isler is an industrial chemist, but also a man of science. He has written and edited numerous publications on the vitamins $\mathrm{A}, \mathrm{E}, \mathrm{K}$ and the carotenoids. The academic community has rewarded him on various occasions for his accomplishments, and these include the Silver-Medal of the ETH in 1935, the Swiss WernerPrice in 1958, an honorary diploma from the ETH in 1975 and last year the Swiss Chemical Society made him an honorary member. Moreover, Isler has been awarded honorary doctorates, one from the University of Amsterdam in 1971 and the other from the University of Basel in 1980. In medicine, his work on the synthesis of vitamin A has not only been important for diseases of nutritional deficiency, other chemists have synthesized derivatives of vitamin A to produce such retinoids as 13-cis-retinoic acid to fight severe and disabling forms of acne. Additional retinoids with specific therapeutic spectra are being created and evaluated today.

Dr. Otto Isler's life spans nearly the whole 20th century, but the impact of his work will continue to exercise its influence far into the 21 st century. Even in the coming age of biotechnology, his synthetic approach will always be looked upon as a model for the pharmaceutical industry. And in those instances where the new paradigm of gene technology cannot fulfill the demands of industry, the methods of Otto Isler and his like will be called upon to accomplish the task.

Dr. Clay E. Reilly

Department of Vitamin and Nutrition Research F. Hoffmann-La Roche Ltd.

$\mathrm{CH}-4002$ Basel 